\title{
The life history of the Long-wattled Umbrellabird Cephalopterus penduliger in the Andean foothills of north-west Ecuador: leks, behaviour, ecology and conservation
}

\author{
OLAF JAHN, EDWIN E. VARGAS GREFA and KARL-L. SCHUCHMANN
}

\section{Summary}

The rare and threatened Long-wattled Umbrellabird Cephalopterus penduliger inhabits the canopy and mid-storey level of humid to wet foothill and montane forests $(150-1,800 \mathrm{~m})$ of the Andean slopes of south-west Colombia and western Ecuador. Here we report on male activity pattern and display behaviour observed at one of two leks recently discovered in the vicinity of Playa de Oro, Rio Santiago, Esmeraldas Province, north-west Ecuador. Courtship behaviour of $C$. penduliger is compared with the Central American and Amazonian congeners (Bare-necked Umbrellabird C. glabricollis and Amazonian Umbrellabird $C$. ornatus). The lek of $C$. penduliger was active during the whole study period (February 1997 to January 1998), but both lek structure and daytime activity pattern changed markedly within the observation period.

\section{Introduction}

The Long-wattled Umbrellabird Cephalopterus penduliger is considered rare and local in humid to wet premontane and cloud forest $(500-1,800 \mathrm{~m}$ ) on the Pacific slopes of south-west Colombia (north to Valle department) and western Ecuador (south to El Oro Province) (Hilty and Brown 1986, Ridgely and Tudor 1994). Occasional records at lower altitudes (including adjacent lowlands) were regarded as altitudinal migration (Ridgely and Tudor 1994). Collar et al. (1994) recently classified this species as Vulnerable due to large-scale habitat destruction (Dodson and Gentry 1991) and hunting for food (Ridgely and Tudor 1994). Here we report on the little-known life history of the Long-wattled Umbrellabird, focusing on lek structure, activity pattern, behaviour, altitudinal range, and aspects of the conservation biology of the species.

\section{Study area}

From August 1995 to March 1998 mist-netting and line transect censuses were carried out in the vicinity of the small village of Playa de Oro $\left(0^{\circ} 52^{\prime} 43^{\prime \prime} \mathrm{N}\right.$ $78^{\circ} 47^{\prime} 37^{\prime \prime} \mathrm{W}$ ), Rio Santiago, Esmeraldas Province, Ecuador (Figure $1 \mathrm{a}, \mathrm{b}$ ). The Playa de Oro commune covers 10,400 ha. At present about 365 ha of this area are actually used for agriculture, and an additional too ha are intensively logged for house and canoe construction. Most of the region is covered by lightly logged 


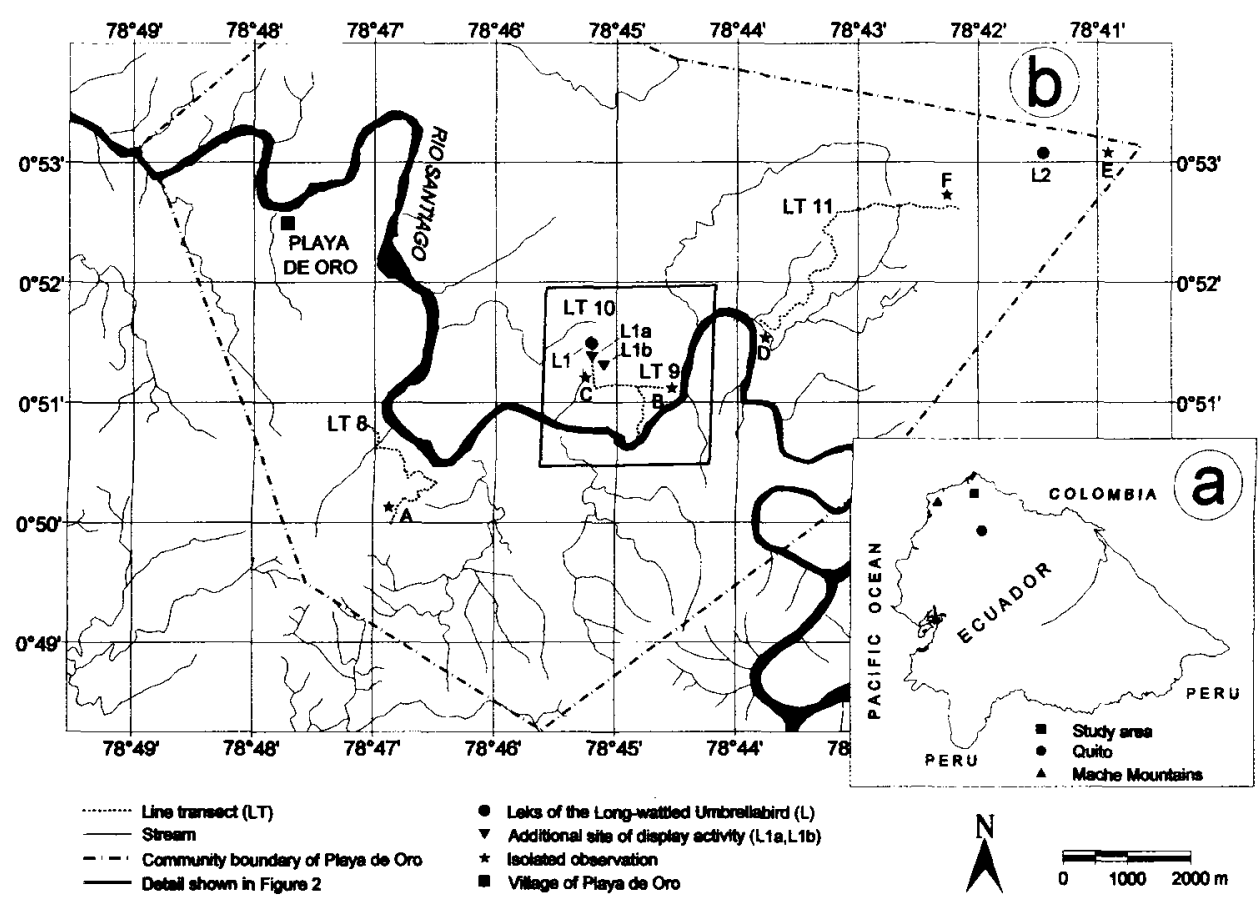

Figure 1. Location of the study area: (a) in Ecuador; (b) observation sites of the Longwattled Umbrellabird in the Playa de Oro commune.

mature as well as primary forest (EcoCiencia 1986, Sierra 1996) and is part of the last significant tract of about $300,000-400,000$ ha of continuous forest in the lowlands, foothills and lower Andean slopes in Esmeraldas Province, Ecuador (Jaramillo et al. 1996). The altitude of the commune ranges from about $45 \mathrm{~m}$ on the downstream banks of the Rio Santiago to about $550 \mathrm{~m}$ in the upper foothill zone of the eastern part of the region. There are no climatic data available for Playa de Oro. However, from existing data in adjacent regions (Cañadas Cruz 1983. Lanfer 1995), we estimate that the mean annual rainfall varies from about $3,000 \mathrm{~mm}$ in the western part of the commune area to about $4,000 \mathrm{~mm}$ in the upper foothill zone. The precipitation pattern for the southernmost part of the Chocó region is seasonal, with wetter periods between January and June, drier periods between July and December.

Compared with other regions of western Ecuador, the bird species diversity is very high: about 315 species have been recorded so far, and we estimate a total of about 400 species (migrants included) as the upper parts of the commune area have not yet been fully investigated.

\section{General observations (Table 1)}

On 27 November 1995 we observed a female Long-wattled Umbrellabird in mature forest in the lower foothills (about $140 \mathrm{~m}$ ), perched 8-12 $\mathrm{m}$ up in the mid-storey (site A on Figure 1b). The bird took wing rather furtively after a few seconds and was not located again. As the observation was made in the dry 
Table 1. Observations of the Long-wattled Umbrellabird in the Playa de Oro commune. All locations are indicated on Figure $1 \mathrm{~b}$. The locations B, C, L1, L1a and L1b are also shown on Figure 2

\begin{tabular}{|c|c|c|c|c|}
\hline $\begin{array}{l}\text { Location on } \\
\text { Figure } 1 b\end{array}$ & Elevation & Date & Time & Observations/remarks \\
\hline A & $140 \mathrm{~m}$ & $\begin{array}{l}27 \text { November } \\
1995\end{array}$ & Late morning & $\begin{array}{l}\text { The first record of a female, which } \\
\text { was misinterpreted as an instance of } \\
\text { altitudinal migration }\end{array}$ \\
\hline$B$ & $150 \mathrm{~m}$ & 30 April 1997 & o8hoo & $\begin{array}{l}\text { A male and a female were observed } \\
\text { about } 1,300 \mathrm{~m} \text { from the first lek }\end{array}$ \\
\hline $\mathrm{C}$ & $200-210 \mathrm{~m}$ & 1 May 1997 & $07 \mathrm{~h} 23$ & $\begin{array}{l}\text { A male and a female were encoun- } \\
\text { tered about } 400 \mathrm{~m} \text { from the first lek }\end{array}$ \\
\hline $\mathrm{D}$ & $(100 \mathrm{~m})$ & 16 June 1997 & - & $\begin{array}{l}\text { Discovery of remains of a male, obvi- } \\
\text { ously killed by poachers; the wattle } \\
\text { had a length of } 33 \mathrm{~cm}\end{array}$ \\
\hline $\mathrm{E}$ & $480 \mathrm{~m}$ & 22 June 1997 & ophzo & $\begin{array}{l}\text { A female was observed at a forest } \\
\text { border by an area cleared by illegal } \\
\text { settlers (colonos) (exact location } \\
\text { unknown) }\end{array}$ \\
\hline F & $380 \mathrm{~m}$ & $\begin{array}{l}16 \text { September } \\
1997\end{array}$ & $08 h_{47}$ & $\begin{array}{l}\text { A female was hunting insects at mid- } \\
\text { storey levels }\end{array}$ \\
\hline L1 & $200-210 \mathrm{~m}$ & see Table 2 & see Table 2 & $\begin{array}{l}\text { The first lek site; records of } 3-6 \text { active } \\
\text { males in all observation months } \\
\text { (February, May, June and July 1997, } \\
\text { January 1998); lek structure and day- } \\
\text { time activity changed markedly } \\
\text { during the observation period (see } \\
\text { Table } 2 \text { and text for details); females } \\
\text { were never actually observed at the } \\
\text { lek }\end{array}$ \\
\hline Lia & $200-210 \mathrm{~m}$ & see Table 2 & see Table 2 & $\begin{array}{l}\text { Additional site of display activity } \\
\text { close to the first lek in July } 1997 \text { and } \\
\text { January } 1998 \text { (see Table 2, Figure } 2 \\
\text { and text for details) }\end{array}$ \\
\hline $\mathrm{Lib}$ & $200-210 \mathrm{~m}$ & see Table 2 & see Table 2 & $\begin{array}{l}\text { Further site of display activity in July } \\
1997 \text { (see Table 2, Figure } 2 \text { and text } \\
\text { for details) }\end{array}$ \\
\hline $\mathrm{L}_{2}$ & $460 \mathrm{~m}$ & 22 June 1997 & o6h10 & $\begin{array}{l}\text { The second lek site (exact location } \\
\text { unknown); intense activity in the } \\
\text { early morning hours with approxim- } \\
\text { ately } 5-10 \text { calling males }\end{array}$ \\
\hline
\end{tabular}

season we interpreted its presence at this locality as an instance of altitudinal migration (see Ridgely and Tudor 1994). Subsequently, however, we realized this conclusion was wrong when a lek of the species was discovered only about 4 $\mathrm{km}$ away from the location where the initial observation was made in $\mathbf{1 9 9 5 .}$

During census work in February 1997 we heard deep far-carrying and prolonged boooh or wooom-calls (Figure 3) from different directions in the forest canopy. As the calls were given only at intervals of several minutes they were difficult to localize and initially we failed to discover the source of the vocalizations. Two months later, however, we encountered a dispersed lek of the Longwattled Umbrellabird in the very same place, and the distinct calls were produced by the displaying males. This lek (L1 on Figures $1 \mathrm{~b}$ and 2) was located within a large section of mature forest on a plateau at an altitude of about 200- 

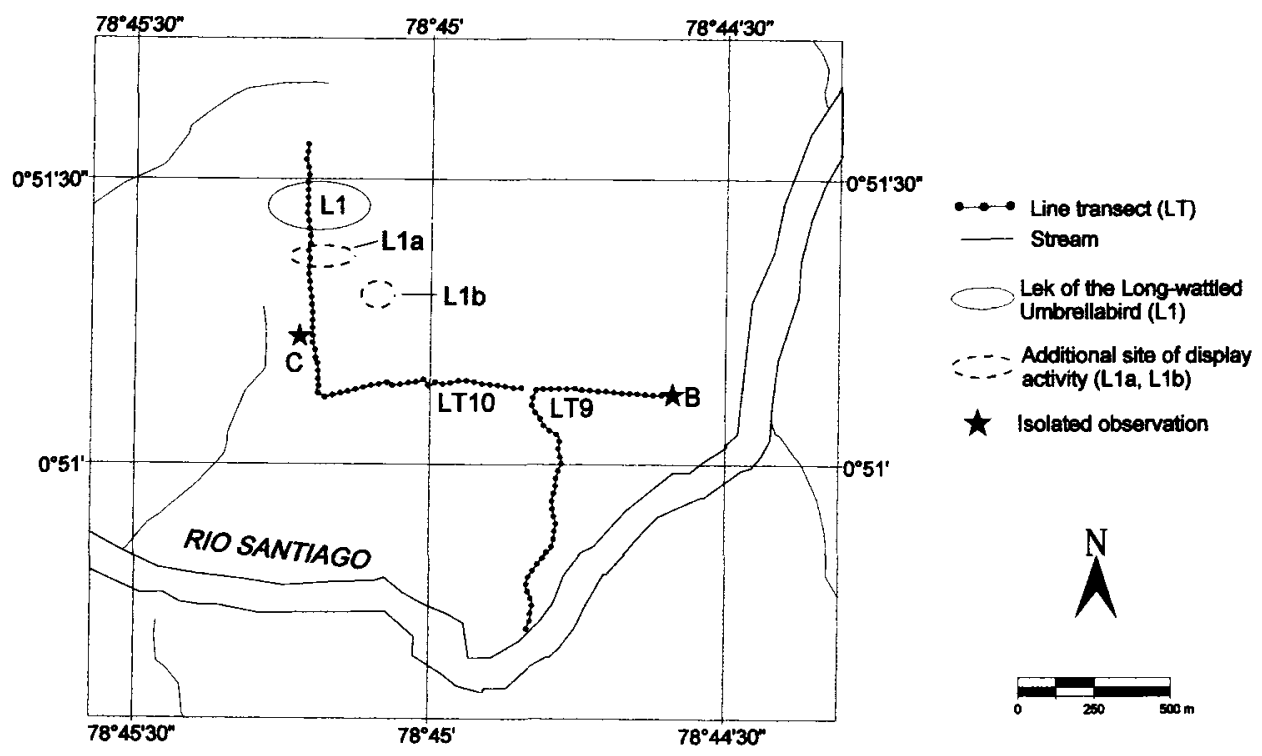

Figure 2. Details of Figure $\mathrm{Ib}$ with the location of the first lek (L1) and the additional sites of display activity (L1a and Lib).

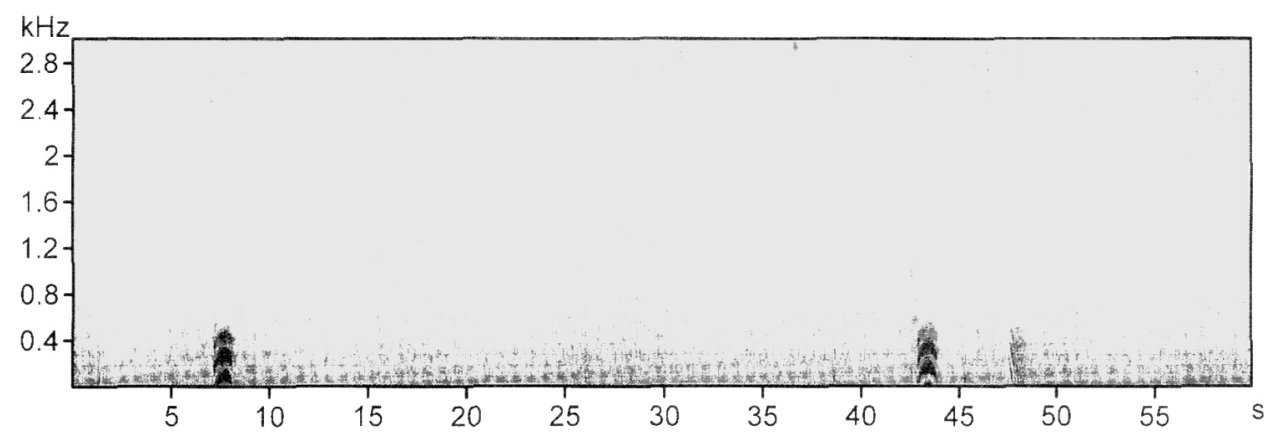

Figure 3. Low frequency boooh calls of a lekking adult male Long-wattled Umbrellabird, Playa de Oro commune, Río Santiago area, Esmeraldas Province, north-west Ecuador.

$210 \mathrm{~m}$. An investigation of the forest structure revealed that local people had selectively logged the plateau at least during the past 15 years. Mostly "Guadaripo" (Ocotea sp.; Lauraceae) and "Anime" (Dacryodes occidentalis and D. cupularis; Burseraceae) had been cut down for canoe construction. To a lesser extent, and in more recent years, "Chanul" (Humiriastrum procerum; Humiriaceae) has also been felled for house construction and for sale on local markets. It was notable that the lek site itself was located inside the most pristine forest patch along the line transect LT 10 (Figure 2), where no logging has occurred within a radius of about $150 \mathrm{~m}$. This area was rich in large trees reaching heights of about 35 to $50 \mathrm{~m}$, and the undergrowth was rather sparse. Some natural treefall gaps were patchily distributed on the periphery of the site. The distance to the Rio Santiago was about $1.3 \mathrm{~km}$. In the early morning and late afternoon two to six active males 
were present at the lek throughout the whole observation period. Each male maintained a distance of $25-50 \mathrm{~m}$ from his neighbour. The dispersed lek was within an area of about $15,000-45,000 \mathrm{~m}^{2}$ (1.5-4.5 ha), estimated with help of the 25-m transect distance-markers.

A second lek (L2) was discovered in June 1997 during our first excursion to the upper foothills of the commune area (Figure $1 \mathrm{~b}$ ). This lek was located at an altitude of about $460 \mathrm{~m}$ and situated approximately $8 \mathrm{~km}$ in a straight line from the first one. The forest structure was quite different compared with the habitat of the first lek. The second area was wetter and the trees were completely enveloped by moss and epiphytes. Larger trees barely reached $30 \mathrm{~m}$ and the forest understorey was dense. Due to the very thick undergrowth it was not possible to walk up to the lek site, but early in the morning (o6h1o) numerous boooh calls were noted per minute, and we estimated that 5 to 10 displaying males were present at this lek.

\section{Display behaviour}

The following description of the courtship behaviour of the Long-wattled Umbrellabird is based on observations at the first lek during line transect censuses on 1 May (about 08h10-10h1o) and on 2 May (about 06h10-07hoo and again about $16 \mathrm{~h} 50-17 \mathrm{~h} 45)$, with an additional observation period between $10 \mathrm{~h} 30$ and 11 h3o on 2 May.

The first boooh calls were heard immediately after dawn from about o6hio, then throughout the morning, with greatest calling activity between $08 \mathrm{~h} 30$ and ogh3o. A marked decrease in calling activity was noted in the late morning hours, increasing again between 17 hoo and sunset. This pattern of daytime activity resembled those of the Amazonian Umbrellabird Cephalopterus ornatus (Sick 1954) and the Bare-necked Umbrellabird C. glabricollis (Cordier 1943). Under optimal conditions (calm, low activity of other birds and insects) the boooh calls were audible at a distance of up to $400 \mathrm{~m}$, estimated with help of the $25-\mathrm{m}$ transect distance-markers. In the early morning and before sunset the calling males were perched high in the canopy. Each male held a display territory and kept at a distance from his neighbouring rivals. During the late morning hours the behaviour pattern changed markedly. At ogh3o faint deep grunting gru, gru, ruh, ruh, gru or bru, bru, uh, uh, gru, gru and similar calls were recorded at the lek site, resembling the low grunts of an alarmed or excited Rock Dove Columba livia, and to some extent also resembling the initial growling of a far distant Red Howler Monkey Alouatta seniculus.

A group of at least six birds was discovered in the canopy and subcanopy of two neighbouring tall trees, hopping and fluttering irregularly among the branches. From time to time a boooh call was emitted, in addition to the grunts. Because of dense vegetation the sex of only two individuals could be confirmed as males. A similar ritualized chasing behaviour was described by Cordier (1943) for the Bare-necked Umbrellabird in Costa Rica.

No gathering was noted in the late morning hours of the additional observation period on 2 May. A single male was observed in the mid-storey about $12 \mathrm{~m}$ up, sitting free of any cover in a loop of liana. Usually rather wary, the bird markedly ignored the approaching observers at the lek location and continued 


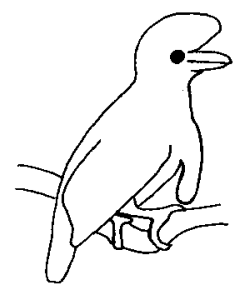

a

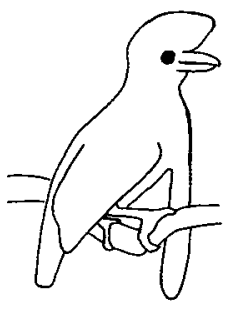

b

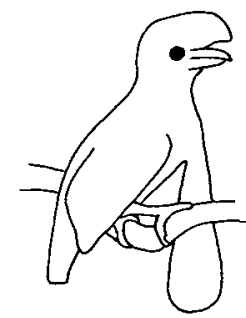

c

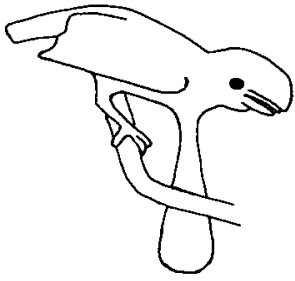

d

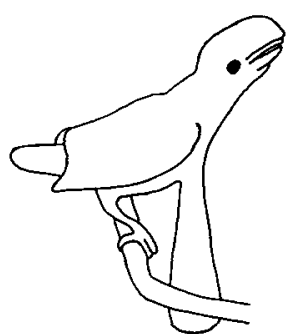

e

Figure 4. Variation of wattle size and umbrella position of male Long-wattled Umbrellabirds depending on the individual's behaviour. (a) A male after landing on a branch. The wattle can be contracted to about one-third of its normal length. The males often shorten the wattle when flying longer distances or in order to preen it. (b) Male with wattle expanded to normal length of $28-35 \mathrm{~cm}$ (Snow 1982, Hilty and Brown 1986). Perching and unexcited males hold the umbrella quite upright. (c) An excited male spreads the umbrella and ruffles out the feathers of his enlarged wattle. (d) The spread crown feathers nearly cover the upper mandible of very excited birds. To fill his air-sacs, the male leans forwards and downwards with his legs straddled, lengthens his freely hanging wattle enormously and ruffles out its feathers. In this stretched forward position the bird remains for a prolonged period (about 20-60 seconds). From time to time he varies the wattle size and shows some choking and pumping movements of the head and neck, sometimes accompanied by low grunting noises. Often, he also opens his bill slightly. (e) Finally the bird utters the boooh call (Figure 3) with a thrust-forward movement of the anterior part of his body. Subsequent to the boooh call the male usually assumes a more upright position, as shown in (b) or (c). (Line drawings by O. Jahn.)

the prolonged preening of his plumage. He preened his wattle intensely, shortened and lengthened it as required and sometimes ruffled out its feathers (Figure $4 \mathrm{a}-\mathrm{c}$ ). At other times he watched out for his rivals in nearby trees.

After 20 minutes, the boooh call was suddenly given by another male. The observed bird reacted very excitedly. He appeared nervous, looked for his competitor, turned around on the same liana, spread his crown feathers so that the upper mandible was nearly covered by the "umbrella", leaned forwards and downwards, lengthened his free-hanging wattle enormously and ruffled out its feathers (Figure 4d). His legs were distinctly straddled. The bird remained in this stretched-forward position for a prolonged period, not only varying the wattle size but also showing some choking and pumping movements of the head and the neck, accompanied by low grunting noises. Approximately 50 seconds passed 
until finally the booo was emitted with a thrust-forward movement of the anterior part of his body (Figure 4e).

Subsequent to the boooh call the male assumed a more upright position, and uttered the faint deep grunting described above. In doing so he expanded his neck, opened his bill slightly, varied the length of the lappet and showed some choking action (Figure $4 \mathrm{a}-\mathrm{C}$ ). Because he expelled a seed at the same time it is not quite clear to what degree different behaviour patterns interfered with this action.

Apparently the lean-forward position and the accompanying choking and pumping actions are necessary to fill the bird's air-sacs, as described earlier by Sick (1954) for the similar behaviour of the Amazonian Umbrellabird in Brazil. An equivalent behaviour pattern has also been described for the display of the Bare-necked Umbrellabird in captivity (Crandall 1945). The complex anatomy required for the generation of the call is probably the reason why the Longwattled Umbrellabird gives the calls only at long intervals, even if more than two displaying males are present at the lek.

In the late afternoon of 28 July 1997, we taped an excited boooh call duel of two not visible but nearby males (Figure 3 ). The taped sequence of calls enables us to calculate the time each male needed at least to fill his air-sacs. The mean length of the intervals for the first male was 34 seconds $(n=7)$ with extremes of 19 seconds and 52 seconds, and for the second male 53 seconds $(n=4)$ with extremes of 47 seconds and 63 seconds. In the late afternoon of 15 January 1998, we measured for one observed male a mean time of 68 seconds $(n=5)$ with extremes of 34 seconds and 118 seconds. Before we actually began to measure the call frequency of this male, we estimated an interval of only 15 to 20 seconds between two successive calls. Apparently such a call frequency is very energy-intensive, since the males had to interrupt their activity for more prolonged periods from time to time. We have to emphasize that the low grunting noises described above are not always uttered by males while filling their air-sacs. Hence these sounds are not an obligatory part of the display-call generation.

Altogether the display behaviour of the Long-wattled Umbrellabird is similar to that of the Amazonian Umbrellabird and the Bare-necked Umbrellabird. However, the formation of defined leks and the gathering and chasing behaviour has not been reported for the Amazonian Umbrellabird. This could be a further argument for the suggestion by Snow (1982) that the Long-wattled Umbrellabird is more closely related to the Bare-necked Umbrellabird, despite the fact that the Long-wattled Umbrellabird looks superficially more like the Amazonian Umbrellabird.

\section{Annual cycle of lek activity}

Both lek structure and daytime activity pattern noted in February and May 1997 were markedly different in July 1997 and January 1998 (Table 2). The first lek site (L1 on Figure 2), described above, still existed at the end of July 1997 but along the transect route we heard the boooh calls at two additional sites in a distance of about 75 to $150 \mathrm{~m}$ each (L1a and Lib on Figure 2). In the late afternoon of 28 July we estimated five to eight calling males at these three sites, with only two active males at the first lek site. During July we observed three males outside 
Table 2. Annual cycle of lek structure and daytime activity at the first lek of the Long-wattled Umbrellabird. The locations L1, L1a and L1b are shown on Figure 2. For each month and each location the observations are ordered as follows: early morning, late morning, late afternoon, date

\begin{tabular}{cccc}
\hline Date & $\begin{array}{c}\text { Location on } \\
\text { Figure } 2\end{array}$ & $\begin{array}{c}\text { Observation } \\
\text { period }\end{array}$ & Observations/remarks \\
\hline
\end{tabular}

\begin{tabular}{|c|c|c|c|}
\hline February 1997 & $\mathrm{~L}_{1}$ & & $\begin{array}{l}\text { All boooh calls were heard from the (sub)canopy at or } \\
\text { close to the first lek site; calling activity was similar } \\
\text { in the early morning and late afternoon; a gathering } \\
\text { or chasing was not noted, but it may have been over- } \\
\text { looked }\end{array}$ \\
\hline 27 February & L1 & o6hog-06h51 & Medium calling activity by about 4 males \\
\hline 28 February & L1 & o8h24-ogh 12 & Low activity; only one call was delivered at $08 \mathrm{~h} 24$ \\
\hline 26 February & L1 & 17 h $45-18$ ho1 & Medium activity by about 4 displaying males \\
\hline
\end{tabular}

May $1997 \quad$ LI

All records of displaying males were concentrated at the first lek site; overall intense display activity with conspicuous gathering and chasing behaviour; on two occasions "pairs" were recorded at a distance of $400 \mathrm{~m}$ and $1,300 \mathrm{~m}$ from the lek (see Table 1 )

\begin{tabular}{|c|c|c|}
\hline 2 May & $\mathrm{L}_{1}$ & o6h12-o7hoo \\
\hline 1 May & $\mathrm{LI}$ & o8h13-roho \\
\hline 2 May & $\mathrm{L}_{\mathbf{1}}$ & roh $30-11 h_{3}$ \\
\hline 2 May & $\mathrm{L}_{1}$ & 16h57-17h \\
\hline June 1997 & $\mathrm{~L} 1$ & \\
\hline
\end{tabular}

Medium calling activity by 3-6 males

Intense activity between $08 \mathrm{~h} 30$ and ogh 30 ; gathering and chasing by at least 6 birds (sex unrecorded); low grunting noises and boooh calls were delivered

Low activity; observation of a male preening his plumage; scattered boooh calls by two individuals

Medium activity by $3-6$ calling males

The species was recorded exclusively at the first lek site during the limited time we spent in the area of Figure 2

11 June

1ohoo-11h3o

Low activity; a few grunting noises by 2 or 3 individuals; a male preening his plumage ignored a group of 6 chattering people

July $1997 \quad$ L1

The activity at the first lek site was much lower in the early morning hours than in the previous months; calling activity was actually greatest in the hour before sunset; the males regularly left the lek during daytime, probably to search for food, and partially gathered and displayed at other sites; we estimated 5-8 active males at the three sites shown on Figure 2

$\begin{array}{lll}28 \text { July } & \text { Li } & \text { o6ho6-o6h43 } \\ 29 \text { July } & \text { Li } & \text { o6h4o-o7h2o }\end{array}$

A few boooh calls delivered by 3 or 4 males

29 July Li o6h40-07h20

27 July $\quad$ L1 $\quad 08 h_{29}-09 h_{4} 8$

Apparently the males had entirely left the lek; a few boooh calls were heard earlier in the morning

28 July LI 17 L $_{53-18 h o 8}$

Low activity by 3 or 4 males; 2 males in a tree behaved passively over a prolonged period

Intense call duel by 2 males (Figure 3); 1 or 2 other males returned to the lek immediately before sunset Some males occurred and displayed at this site with overall low intensity; the possibility that they gathered in fruiting trees seems likely, but has yet to be proven

28 July L1a o7h11-o $7 \mathrm{~h}_{52}$

At least 2 males were encountered here (one uttered the boooh call, another perched high in a dead tree and left in direction of the first lek); most probably the birds moved around to look for food 
Table 2. (cont.)

\begin{tabular}{|c|c|c|c|}
\hline Date & $\begin{array}{l}\text { Location on } \\
\text { Figure } 2\end{array}$ & $\begin{array}{l}\text { Observation } \\
\text { period }\end{array}$ & Observations/remarks \\
\hline \multirow[t]{2}{*}{28 July } & Lra & ${ }_{17 h_{45}-17 h_{53}}$ & $\begin{array}{l}1 \text { or } 2 \text { males delivered some boooh calls possibly on } \\
\text { passage to the lek }\end{array}$ \\
\hline & $L_{1} b$ & & $\begin{array}{l}\text { Boooh calls were repeatedly heard at this location; it } \\
\text { seems possible that the males gathered in fruiting } \\
\text { trees }\end{array}$ \\
\hline 29 July & Lib & $05 h_{50}-06 h_{30}$ & $\begin{array}{l}\text { A single boooh call was heard immediately after dawn } \\
\text { at a distance of at least } 200 \mathrm{~m} \text { from the transect; it is } \\
\text { almost certain that the male had roosted at this site }\end{array}$ \\
\hline 28 July & $\mathrm{Lib}$ & 17h16-17h45 & $\begin{array}{l}\text { High calling activity by about } 3 \text { males at a distance of } \\
200 \text { to } 300 \mathrm{~m} \text { from the transect }\end{array}$ \\
\hline January 1998 & L1 & & $\begin{array}{l}\text { Overall activity was low and only about } 4 \text { active } \\
\text { males were present in the area; as in July } 1997 \text { they } \\
\text { tended to leave the lek during daytime and partially } \\
\text { gathered and displayed at another site }\end{array}$ \\
\hline 14 January & L1 & $06 h_{12-06 h 41}$ & Medium calling activity by at least 4 males \\
\hline 17 January & L1 & o6h10-o7hoo & No calling activity during light rainfall \\
\hline 16 January & L1 & o8h28-10ho3 & Low activity by about 3 or 4 males \\
\hline 14 January & L1 & 17h23-18ho5 & Several boooh calls by at least 4 males \\
\hline 15 January & L1 & 15 hoo-17h5o & $\begin{array}{l}\text { Begin of calling activity at } 16 \text { h } 30 \text {; only about } 10 \text { boooh } \\
\text { calls by about } 4 \text { different males were heard until dark }\end{array}$ \\
\hline \multirow[t]{2}{*}{16 January } & L1 & 16 hoo-17h35 & $\begin{array}{l}\text { Between } 16 \text { h15 and } 16 \text { h } 45 \text { only } 4 \text { boooh calls by a single } \\
\text { male; at } 16 \text { h52 a second male appeared at the lek; the } \\
\text { two males kept at a distance of } 15-20 \mathrm{~m} \text { from each } \\
\text { other and uttered a few of the low grunting noises } \\
\text { and boooh calls; no other males were recorded at this } \\
\text { site }\end{array}$ \\
\hline & Lia & 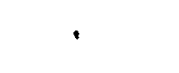 & $\begin{array}{l}\text { As in July } 1997 \text { calling males were repeatedly } \\
\text { recorded at this location }\end{array}$ \\
\hline 14 January & Lia & $06 \mathrm{~h}_{57}-07 \mathrm{~h}_{2} 8$ & $\begin{array}{l}\text { Several boooh calls by different individuals; } 2 \text { males } \\
\text { overflew the transect }\end{array}$ \\
\hline 16 January & Lia & 17ho4 & A boooh call was heard at this site \\
\hline
\end{tabular}

the first lek in the early morning hours, apparently moving around looking for food. We estimated that the activity area around the first lek had the dimension of a square of at least 25 to 50 ha during this period of the year.

Calling activity was low between o6h1o and $06 \mathrm{~h} 30$ on 28 and 29 July and later only scattered boooh calls were emitted. About $06 \mathrm{~h}_{40}$ on $29 \mathrm{July}$ the males had apparently left the first lek site and were probably searching for food. Between o8h3o and ogh4o on 27 July a few boooh and grunting calls were heard at the lek and two males were discovered in the same tree. Neither seemed much disturbed by the presence of another male at the same location, because they behaved markedly passively over a long period. In contrast to the situation observed in other months, in July 1997 calling activity was low in the early morning hours and greatest in the hour before sunset.

In January 1998 we encountered only about four active males in the area of the first lek. As in July 1997 they tended to leave the lek during daytime and partially gathered and displayed at another site (Lia on Figure 2). In general, activity was low even in the early morning and late afternoon. 
The described changes in lek structure and daytime activity pattern could be a consequence of differences in the distribution pattern of food resources within the study period. It seems likely that the additional sites of display activity were formed by males gathering in fruiting trees and that males feeding nearby provoked them to utter the boooh calls. It is not quite clear yet if the total number of active males really increased in July 1997 or if the individuals present were more noticeable because they conspicuously moved around a lot.

We never really observed a female at the lek. Only on 30 April and on 1 May 1997 were "pairs" noted about $400 \mathrm{~m}$ and 1,300 $\mathrm{m}$ from the first lek site (sites C and B, respectively on Figures $\mathrm{Ib}$ and 2). In general, "pairs" of Long-wattled Umbrellabird are regularly reported outside leks, as described by Ridgely and Tudor (1994). Sick (1954) reported that calling males of the Amazonian Umbrellabird were regularly associated with a female in Brazil. It seems likely, however, that such associations are temporary (Snow 1982).

The intense display activity with the remarkable gathering and chasing behaviour at the first lek site in May 1997, and the observation of two females (in "pairs") in the vicinity of the lek in the same period, could be an indication that the breeding season of the Long-wattled Umbrellabird coincides with the rainy season. However, no information is available about its breeding, as the nest records given by Goodfellow (1901) and Hagen (1938) are doubtful (Snow 1982). Our knowledge of the annual cycle of the species is still incomplete, as it was not possible to visit the lek from August to December 1997. It seems likely that the lek was active throughout 1997, although with varying intensity. July 1997 was already influenced by the strong El Niño effect of 1997/1998, hence the climate was not as dry as usual. It is possible that the males leave the lek in very dry periods due to shortages of food and migrate seasonally and altitudinally, as assumed by Ridgely and Tudor (1994). The moult records of all umbrellabirds show no distinct seasonal pattern and for the Amazonian Umbrellabird it has been mentioned that breeding is independent of the seasons (Snow 1982). In contrast, a marked annual cycle, including altitudinal migration is confirmed for the Bare-necked Umbrellabird (Slud 1960, Stiles and Skutch 1989, Collar et al. 1992).

\section{General biology and conservation}

Further research is needed as many aspects of the natural history of the Longwattled Umbrellabird remains unknown. Goodfellow (1901) and Hagen (1938) suggested that palm fruits are an important part of the diet but, except for a regurgitated seed, the only direct observations we made of foraging was one male that caught a butterfly at the lek location, and a female that hunted insects at mid-storey levels (site F on Figure 1 b).

Questions closely connected to conservation biology are of particular interest. For example: are the lek sites of the Long-wattled Umbrellabird traditional or not? What are the habitat characteristics of the lek sites? At what distance from the lek do the females nest, and in this context what is the minimum size of forest fragment sufficient to support the reproduction of the species? Is seasonal or altitudinal migration necessary for its survival? Are lek sites in the altitude 
range between $200 \mathrm{~m}$ and $500 \mathrm{~m}$, as described above, really an exception or rather quite normal?

A population of the Long-wattled Umbrellabird was discovered recently (Parker and Carr 1992) in the Montañas de Mache, which is a coastal mountain system in the western part of Esmeraldas Province (Figure 1a). The highest ridges of these mountains do not exceed 600-800 $\mathrm{m}$ (Wege and Long 1995). The species is also reported from both protected areas of this region, the Jatun Sacha Bilsa Biological Reserve $(400-700 \mathrm{~m})$ and a newly created neighbouring reserve (D. Pearson, pers. comm.). The lowest part of this area still covered by forest in near-pristine condition is located at an altitude of 100-300 $\mathrm{m}$ (Best and Kessler 1995). The Long-wattled Umbrellabird was frequently recorded around the buildings in the Jatun Sacha Bilsa Biological Reserve (Best et al. 1997). It would be most instructive to know within which altitudinal range the leks there are formed. As the coastal mountain system has been isolated from the Andes for decades, due to rapid deforestation in the lowlands of western Ecuador since the 1950 (Dodson and Gentry 1991), it is safe to assume that this population is no longer able to perform altitudinal movements above $600-800 \mathrm{~m}$.

The conservation status of the forest in the Rio Santiago area, where the two leks are located, is not secure. In recent years Playa de Oro has faced increasing pressure from illegal settlers (colonos) and poachers. They penetrate the area from the already over-hunted and extensively deforested region of Lita and by way of the recently constructed road between Ibarra (Imbabura Province) and San Lorenzo (Esmeraldas Province).

The lek ( $\mathrm{L}_{2}$ on Figure ${ }_{1} \mathrm{~b}$ ) encountered in the upper foothills of the commune is located only about $2 \mathrm{~km}$ from a 16-ha area of cultivated land inside the forest, cleared by one colono family within the last 10 years. At the forest border close to their hut we observed a female Long-wattled Umbrellabird in June 1997 (site E on Figure 1). In the same month we found a lower mandible connected to the skin of the throat and the wattle of an adult male Long-wattled Umbrellabird in a camp obviously constructed by poachers (site D on Figure 2).

The first lek is located in the centre of a management plan area for sustainable forestry facilitated by the SUBIR Project, CARE/Ecuador and the Ecuadorian NGO Fundación Jatun Sacha in cooperation with Playa de Oro. Low-impact timber exploitation trials began in 1997 in a forest section only about $1.5 \mathrm{~km}$ from the lek. These organizations are very conscious of the occurrence of the Long-wattled Umbrellabird and Playa de Oro is determined to exclude the lek and the surrounding areas from the management plan. But as local people obtain protein-rich food mainly by hunting, this does not guarantee the survival of the lek. On 11 June O.J. visited this lek site with a group of people from the several organizations involved in the management plan project. Within two minutes they found a male, and as in an earlier situation described above he did not seem to be disturbed by a group of six chattering people. So it is very easy to approach the males at the lek and consequently very difficult to avoid direct persecution of the lekking males by local hunters. On behalf of the SUBIR Project, and together with the Ecuadorian NGO EcoCiencia, O.J. will prepare a protection strategy for the lek area, which will take into account its potential for ecotourist activity. It seems that no other strategy could better guarantee the maintenance 
of the lek than the creation of an income for the local people based on the lek itself.

In the management plan area, during 12 line transect censuses on three days in February and on two days in May 1997, O.J. recorded four globally threatened species (Collar et al. 1994), namely the Baudo Guan Penelope ortoni, Five-coloured Barbet Capito quinticolor, Long-wattled Umbrellabird and Scarlet-breasted Dacnis Dacnis berlepschi, and five locally threatened species (Granizo et al. 1997), the Crested Guan Penelope purpurascens, Tawny-faced Quail Rhynchortyx cinctus, Great Green Macaw Ara ambigua, Rufous-crowned Antpitta Pittasoma rufopileatum, and Blue-whiskered Tanager Tangara johannae. Only four of these threatened species were noted in the preceding inventory of biodiversity carried out in the area (Benitez and Matheus 1997), probably due to the absence of an appropriate and standardized method for a rapid assessment of bird communities. This case provides us with one more example of the urgent need for rapid assessment methods, not only for bird communities but also for other taxa, in order to carry out environmental impact assessments, as outlined in the Convention on Biological Diversity (UNEP 1992).

\section{Acknowledgements}

This work is a result of the project "Birds as Indicators for Human-influenced Tropical Habitats" (project no. 90.2136.1-03.100) and is part of the "Tropenökologisches Begleitprogramm" (TÖB) of the Deutsche Gesellschaft für Technische Zusammenarbeit, GTZ, Germany. The study would have been impossible without the additional financial support of the Brehm-Fund for International Bird Conservation, Germany. The project was carried out in cooperation with the Fundación para el Estudio e Investigación de los Colibries Ecuatorianos (FEICE), Quito, as a national partner, with the Fundación Ecuatoriana de Estudios Ecológicos (EcoCiencia), Quito, as a logistical partner, and with the logistic help, for which we are most grateful, of the SUBIR Project, CARE/Ecuador, and the Deutscher Entwicklungsdienst, DED, Germany. We would like to thank the Instituto Ecuatoriano Forestal de Areas Naturales y Vida Silvestre (INEFAN), Quito, for permission to work in Ecuador and the community of Playa de Oro for permission to work on their land. We thank Jody Stallings (coordinator of the SUBIR Project), Walter Palacios (coordinator of the management plan, Jatun Sacha) and Rocio Alarcón (coordinator of the department for biological studies, EcoSciencia) for inspiring discussions about environmental impact assessments for sustainable forestry in Esmeraldas Province, for their efforts to adapt the management plan of Playa de Oro to new information on the occurrence of threatened bird species and for critical comments on the manuscript; Paola Gabriela Castañeda Guayasamín and Martín Rafael Bustamante Rosero for the determination of the altitude, orientation and inclination of the transects and Laura Arcos, former dean of the department of biology of the Universidad Católica del Ecuador, Quito, for her help to find these dedicated students; Fernando Rodriquez, Guillermo Sanchez and Belen Herrera from the Geographical Information System (GIS) Laboratory of EcoCiencia for the preparation of the maps; Patricio Mena Valenzuela (EcoCiencia) for exchanges of information; Anna Treydte, Cornelia Haffner and Brian Hillcoat for comments on the manuscript. Elisabeth Kietzmann, Katja Kunz, Christa Budde and Thomas Züchner provided various logistic help during the preparation of the manuscript. We also thank David Pearson for his great interest in the project, exchanges of information and critical comments on the manuscript; in fact he was the first to assume that the boooh calls were uttered by the Long-wattled Umbrellabird when he heard the description of the vocalizations during a meeting in Quito. 


\section{References}

Benítez, V. and Matheus, J.C. (1997) Diversidad y abundancia relativa de las aves en dos localidades en Playa de Oro, zona de amortiguamiento de la Reserva Ecológica Cotacachi-Cayapas, Esmeraldas, Ecuador. In P.A. Mena, A. Soldi, R. Alarcón, C. Chiriboga and L. Suárez (eds.) Estudios Biológicos para la Conservación. Diversidad, Ecologia y Etnobiologia. Quito, Ecuador: EcoCiencia.

Best, B.J. and Kessler, M. (1995) Biodiversity and conservation of Tumbesian Ecuador and Peru. Cambridge, U.K.: BirdLife International.

Best, B.J., Heijnen, T. and Williams R.S.R. (1997) A guide to bird-watching in Ecuador and the Galápagos Islands. West Yorkshire, U.K.: Biosphere Publications.

Cañadas Cruz, L. (1983) El mapa bioclimático y ecológico del Ecuador. Quito, Ecuador: Banco Central.

Collar, N.J., Gonzaga, L.P., Krabbe, N., Madroño Nieto, A., Naranjo, L.G., Parker, T.A., III and Wege, D.C. (1992) Threatened birds of the Americas: the ICBP/IUCN Red Data Book. Cambridge, U.K.: International Council for Bird Preservation.

Collar, N.J., Crosby, M.J. and Stattersfield, A.J. (1994) Birds to watch 2: the world list of threatened birds. Cambridge, U.K.: BirdLife International (BirdLife Conservation Series 4).

Cordier, C. (1943) The Umbrella Bird comes to the Zoo. Anim. Kingdom 45: 3-10.

Crandall, L.S. (1945) The Umbrella Bird is not a dull fellow any more. Anim. Kingdom 48 : 109-112.

Dodson, C.H. and Gentry, A.H. (199x) Biological extinction in western Ecuador. Ann. Missouri Bot. Gard. 78: 273-295.

EcoCiencia (1986) Mapa de uso actual y uso potencial-comuna Playa de Oro. Quito, Ecuador: EcoCiencia, INEFAN, USAID, CARE-SUBIR.

Goodfellow, W. (1901) Results of an ornithological journey through Colombia and Ecuador. Ibis 1: 300-319, 458-480, 699-715.

Granizo, T., Guerrero, M., Pacheco, C., Phillips, R., Ribadeneira, M.B. and Suárez, L. (1997) Lista de aves amenazadas de' extinctión en el Ecuador. Quito, Ecuador: UICN-Sur, CECIA, INEFAN, EcoCiencia and BirdLife International.

Hilty, S.L. and Brown, W.L. (1986) A guide to the birds of Colombia. Princeton, N.J.: Princeton University Press.

Jaramillo, H., Arévalo, A., Rubio, D. and Vollmer, U. (1996) Estrategia regional y plan de acción emergente para promover el desarrollo forestal sustentable en la provincia de Esmeraldas. Esmeraldas, Ecuador: Unidad Coordinadora para el desarrollo forestal sustenable en Esmeraldas.

Lanfer, N. (1995) Wasserbilanz und Bestandsklima als Grundlage einer agrarklimatischen Differenzierung in der Costa Ecuadors. Göttingen, Germany: Verlag Erich Goltze (Göttinger Beiträge zur Land- und Forstwirtschaft in den Tropen und Subtropen 104).

Parker, T.A., III and Carr, J.L. (1992) Status of forest remnants in the Cordillera de la Costa and adjacent areas of southwestern Ecuador. RAP Working Papers no. 2. Washington, D.C.: Conservation International.

Ridgely, R.S. and Tudor, G. (1994) The birds of South America, II. The suboscine passerines. Oxford, U.K.: Oxford University Press.

Sick, H. (1954) Zur Biologie des amazonischen Schirmvogels, Cephalopterus ornatus. J. Ornithol. 95: 233-244.

Sierra, R. (1996) La deforestación en el Noroccidente del Ecuador 1983-1993. Quito, Ecuador: EcoCiencia.

Slud, P. (1960) The birds of Finca "La Selva", Costa Rica: a tropical wet forest locality. Bull. Am. Mus. Nat. Hist. 121: 53-148.

Snow, D.W. (1982) The cotingas: bellbirds, umbrellabirds and other species. New York: Cornell University Press. 
Stiles, F.G. and Skutch, A.F. (1989) A guide to the birds of Costa Rica. London, U.K.: Christopher Helm.

UNEP (1992) Convention on biological diversity, 5 June 1992. United Nations Environment Programme No. 92-7807.

von Hagen, W. (1938) On the capture of the Umbrella Bird (Cephalopterus penduliger Sclater). Proc. Zool. Soc. Lond. 108: 27-30.

Wege, D.C. and Long, A.J. (1995) Key areas for threatened birds in the Neotropics. Cambridge, U.K.: BirdLife International (BirdLife Conservation Series 5, p. 311).

\section{OLAF JAHN}

Fundación Ecuatoriana de Estudios Ecológicos, EcoCiencia, Isla San Cristóbal 1523 e Isla Seymour, P.O. Box 17-12-257, Quito, Ecuador and Alexander Koenig Research Institute and Museum of Zoology, Research Group "Biology and Phylogeny of Tropical Birds", Adenauerallee 160, D-53113 Bonn, Germany.

EDWIN E. VARGAS GREFA

Fundación Ecuatoriana de Estudios Ecológicos, EcoCiencia, Isla San Cristóbal 1523 e Isla Seymour, P.O. Box 17-12-257, Quito, Ecuador.

\section{KARL-L. SCHUCHMANN}

Alexander Koenig Research Institute and Museum of Zoology, Research Group "Biology and Phylogeny of Tropical Birds", Adenauerallee 160, D-53113 Bonn, Germany.

email: kl.schuchmann.zfmk@uni-bonn.de 